Revista de Ciencias Sociales - Número 65 (2014) - Páginas 47-87

Acerca del antirrepresentacionalismo de Richard Rorty

\title{
ACERCA DEL ANTIRREPRESENTACIONALISMO DE RICHARD RORTY
}

\author{
ABOUT THE ANTIREPRESENTATIONALISM \\ OF RICHARD RORTY
}

IGNACIO VÁSQUEZ CACES*

Programa de Doctorado en Derecho, Universidad de Valparaíso ivasquez@senado.cl

\section{Resumen}

La presente comunicación, de carácter descriptivo, da cuenta de algunos de los aspectos principales que articulan el llamado antirrepresentacionalismo que fuera defendido por el filósofo pragmatista Richard Rorty. Además, contiene una explicación sucinta del modo en que la noción rortiana de etnocentrismo opera como enlace entre el antirrepresentacionalismo y el liberalismo para, finalmente, proponer a la filosofía como una forma de conversación y práctica social.

\section{Palabras claves}

Antirrepresentacionalismo, pragmatismo, etnocentrismo.

* Abogado. Magíster en Derecho, Universidad Internacional de Andalucía

(España), Doctor (c) en Derecho, Universidad de Valparaíso (Chile). Este artículo ha sido estructurado a partir de la tesis doctoral del autor. Artículo recibido el 27 de noviembre de 2014 y aceptado el 11 de noviembre de 2014.

Revista de Ciencias Sociales - Número 65 (2014) - Universidad de Valparáíso - ISSN 0716-7725-Valparaíso, Chile 


\begin{abstract}
This communication, descriptive, shows some of the main aspects that articulate the so-called antirepresentationalism which was defended by the pragmatist philosopher Richard Rorty. It also contains a brief explanation of how the rortian's notion of ethnocentrism operates as a link between the antirepresentationalism and liberalism to, finally, propose to philosophy as a form of conversation and social practice.
\end{abstract}

\title{
Keywords
}

Antirepresentationalism, pragmatism, ethnocentrism.

\section{Introducción}

La obra del filósofo norteamericano Richard Rorty (Nueva York, 1931-Palo Alto, California, 2007), no ha estado exenta de fuertes críticas provenientes de relevantes pensadores como Habermas, Lyotard o Putnam. Sin embargo, merced a su agudo humor ironista, es probable que él haya podido leer las objeciones a su obra sin tomárselas demasiado en serio y desde una saludable distancia respecto de sí mismo. Lo que me interesa destacar, ahora, es que a partir de la originalidad de su pensamiento en Rorty descubrimos una actitud auténticamente liberal y que supone, en el seno de la diversidad humana, una renovada disposición al debate y a la conversación sin ningún anclaje dogmático.

La lectura de Richard Rorty nos exhorta a considerar la posibilidad de que no exista un modo de ser real de las cosas, sino sólo descripciones más o menos útiles del mundo: metáforas que en un momento determinado de la historia son más exitosas que otras, en función de nuestros intereses y necesidades, para habérnoslas con aquello que llamamos realidad. En tal sentido la perspectiva pragmatista rortiana se desapega de la metafísica y se sitúa en una posición que implica un rechazo de la noción de verdad absoluta, que pasa entonces a ser circunstancial y convencional. Éste es el núcleo del antirrepresentacionalismo rortiano. Si a la luz del nominalismo historicista rortiano somos resultado del tiempo y del azar es implausible sostener una racionalidad ahistórica, que esté fuera de nuestra piel y de la contingencia radical

Facultad de Derecho y Ciencias Sociales - Universidad de Valparaíso - Chile 
del lenguaje. En circunstancias que la pregunta pragmatista medular es cómo podemos mejorar nuestro futuro y la respuesta exige ampliar poéticamente las posibilidades de nuestra imaginación, el pensamiento de Rorty es una permanente invitación a no ceder ante el miedo y los prejuicios: esta clase de disposición al encuentro con otros constituye la vía para un mundo nuevo, en el que las generaciones venideras sean más libres en una comunidad que nuestro autor visualiza de carácter democrática, progresista y pluralista.

\section{Superación pragmatista del concepto de "verdad"}

Comenta Hilary Putnam que antes de Kant los filósofos en general aceptaban la concepción de que la verdad es un tipo de correspondencia entre las ideas y lo que es el caso: existe un mundo en el exterior y lo que decimos o pensamos es "verdadero" cuando captamos la forma en que es y "falso" cuando no corresponde a la forma en que es ${ }^{1}$. Con Kant, agrega Putnam, surge una nueva perspectiva según la cual la verdad es radicalmente dependiente de la mente. En la actualidad las concepciones sobre la verdad son de dos clases: la "realista", que la interpreta como un tipo de correspondencia con lo que es el caso, y la "verificacionista" que la interpreta como lo que podría verificarse bajo condiciones ideales de investigación. Hubo, sin embargo, filósofos de corte empirista que a comienzos del siglo XX no adscribieron a ninguna de estas concepciones: estos autores rechazaron la noción total de "verdad" como metafísica. Putnam ejemplifica esta posición con John Dewey, que siempre aludió a aseverabilidad justificada (o asertabilidad garantizada) y no a verdad — para Dewey la expresión asertabilidad garantizada está libre de las ambigüedades de los términos "creencia” y "conocimiento". Enseguida Putnam recuerda que para algunos

1. PUTNAM, Hilary: El significado y las ciencias morales (traducción de Ana Isabel Stellino). Universidad Nacional Autónoma de México, Instituto de Investigaciones Filosóficas, Colección Cuadernos N 55, México D.F., 1991, p. 9.

2. DEWEY, John: La miseria de la epistemología. Ensayos de pragmatismo (traducción de Ángel M. Faerna). Editorial Biblioteca Nueva S.L., Madrid, 2010, p. 134.

Revista de Ciencias Sociales - Número 65 (2014) - Universidad de Valparaíso - ISSN 0716-7725-Valparáís, Chile 
pragmatistas "verdadero" es una noción metafísica porque las adscripciones al predicado "verdadero" nunca podrán ser verificadas o falseadas: si bien podemos decir de un juicio que está confirmado hasta cierto punto, como una confirmación perfecta es imposible jamás se podrá verificar si el juicio es absolutamente verdadero ${ }^{3}$. El realista considera que el lenguaje no refleja al mundo, sino que son los hablantes quienes reflejan al mundo (a su ambiente), "en el sentido de que construyen una representación simbólica de ese ambiente"4.

En el planteamiento pragmatista de Dewey toda aserción garantizada depende de la investigación y la investigación está conectada, por definición, con lo que es cuestionable y cuestionado: esto no sólo conlleva cierto falibilismo, sino que también remite a la probabilidad (y a la determinación de grados de probabilidad), puesto que rechaza todo enunciado intrínsecamente dogmático, esto es, cualquier enunciado del que se afirme "que posee una verdad

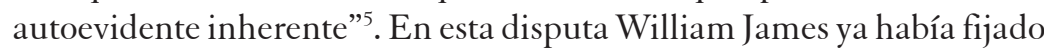
el derrotero del pragmatismo en las conferencias que ofreciera en 1906 y 1907 en el Lowell Institute, de Boston, y en la Columbia University, de Nueva York, respectivamente, cuando declaró al pragmatismo alejado de abstracciones e insuficiencias, de soluciones verbales, de malas razones a priori, de principios inmutables, de sistemas cerrados y pretendidos absolutos y orígenes, para optar por lo concreto y adecuado, los hechos, la acción y el poder ${ }^{6}$.

En su introducción a Consecuencias del pragmatismo el filósofo Richard Rorty aduce que para el pragmatista la verdad no es la clase de cosa sobre la que quepa esperar una teoría de interés filosófico, en cuanto "verdad" es simplemente el nombre de una propiedad que todos los

3. PUTNAM, Hilary: ob. cit., pp. 9-11.

4. Ídem, p. 142.

5. DEWEY, John: ob. cit., p. 137.

6. JAMES, William: Pragmatismo (traducción de Luis Rodríguez Aranda, $3^{a}$ edición). Editorial AGUILAR-Biblioteca de Iniciación Filosófica, Buenos Aires, 1961, p. 57.

Facultad de Derecho y Ciencias Sociales - Universidad de Valparaíso - Chile 
enunciados verdaderos comparten. Los pragmatistas — agrega — dudan de la utilidad de un estudio acerca de este rasgo común, al igual que dudan que haya algo que decir sobre el rasgo común que comparten acciones moralmente plausibles ${ }^{7}$. Desde el punto de vista de los pragmatistas la historia de los intentos fallidos de aislar lo Verdadero o lo Bueno, o de definir los términos "verdadero" o "bueno", así como la historia de las disputas en torno a esos mismos objetivos, refuerza su sospecha de que todo lo que se haga en el ámbito de una teoría de la verdad carece de interés ${ }^{8}$.

Para el pragmatismo la noción de verdad traduce el poder directivo o conductor que tienen las ideas. En circunstancias que el pragmatista considera que lo Verdadero se rige por el principio de utilidad (de lo que funciona y sirve para cierto propósito), el pragmatismo — como señala Dewey - es aquella concepción que presupone "que las ideas son esencialmente intenciones (planes y métodos) y que lo que en última instancia pretenden, en cuanto que ideas, tiene un carácter prospectivo: ciertos cambios en las cosas previamente existentes" . Lo anterior se contrapone al racionalismo y su teoría de la copia, donde las ideas — en cuanto que ideas- "son ineficaces e impotentes desde el momento en que sólo tratan de reflejar como en un espejo una realidad que ya está completa sin ellas" ${ }^{10}$. En un comentario a la obra de William James, contenido en el ensayo Qué entiende el pragmatismo por "práctico" de 1908, Dewey hace hincapié en las dos conclusiones principales en torno al carácter de las verdades como "hechos consumados" a que arribara James en su disputa con el racionalismo: por una parte, que las verdades son construidas, esto es, no son a priori ni existen eternamente; por otra, que su valor o importancia no es estática, sino dinámica y práctica ${ }^{11}$.

7. RORTY, Richard: Consecuencias del pragmatismo (traducción de José Miguel Esteban Cloquell). Editorial TECNOS S.A., Madrid, 1996b, p. 19.

8. Íd. ibíd.

9. DEWEY, John: ob. cit., p. 82.

10. Íd. ibíd.

11. Íd. ibíd.

Revista de Ciencias Sociales - Número 65 (2014) - Universidad de Valparaíso - ISSN 0716-7725-Valparaíso, Chile 
Rorty trae a colación que al comparar enunciados como "ayer llovió" y "los hombres deben procurar ser justos en su trato mutuo" las aguas se dividen entre platónicos y positivistas. Así mientras para Platón los enunciados del primer tipo eran mera doxa y los del segundo un candidato plausible a episteme, para la tradición positivista la primera oración constituía el paradigma de lo que la Verdad representaba y la última era una simple predicción o la expresión de una emoción ${ }^{12}$. El pragmatismo "borra" la distinción trascendental/empírico y coloca en duda la presuposición común por la que puede establecerse una comparación entre ambos tipos de verdades: si las oraciones verdaderas no lo son porque correspondan a la realidad, es inoficioso preguntarse a qué tipo de realidad corresponde una oración. En tanto radical antiplatónico el pragmatista lleva la idea baconiana de que el conocimiento es poder hasta su extremo, cosa que no hace el positivista. Al renunciar a la noción de verdad como correspondencia con la realidad, para el pragmatista la afirmación "las oraciones verdaderas funcionan porque corresponden con el modo de ser de las cosas" no es más iluminadora que la afirmación "algo es bueno porque cumple la Ley Moral”. En su concepto ambas observaciones son vacuos cumplidos metafísicos ${ }^{13}$. De allí es que no es dable equiparar la propuesta pragmatista de autores como James o Dewey —los "grandes pragmatistas”, Rorty dixit - con una variación holística del empirismo lógico, sino con una "ruptura con la tradición epistemológica kantiana en su conjunto" 14 .

La definición que ofrece Richard Rorty de antirrepresentacionalismo es la siguiente: "Entiendo por explicación antirrepresentacionalista una explicación según la cual el conocimiento no consiste en la aprehensión de la verdadera realidad, sino en la forma de adquirir hábitos para hacer frente a la realidad"15. Es clave para esta perspectiva

12. RORTY, Richard: ob. cit., p. 22.

13. Íd., pp. 22-23.

14. Íd., p. 241.

15. RORTY, Richard: Objetividad, relativismo y verdad (traducción de Jorge Vigil, $1^{a}$ edición). PAIDÓS Ibérica S.A., Barcelona, 1996a, p. 15.

Facultad de Derecho y Ciencias Sociales - Universidad de Valparaíso - Chile 
—en sintonía con Donald Davidson - la conexión con los usuarios del lenguaje: "Una explicación completa de la verdad debe, por tanto, ponerla en relación con la interacción lingüística real” ${ }^{16}$. Una explicación de carácter antirrepresentacionalista torna innecesaria la distinción —al estilo Dilthey - entre explicar y comprender, porque la diferencia entre ambas actividades es sociológica y no epistemológica ${ }^{17}$. Con generalidades universales de tipo platónico, tales como verdad necesaria o forma lógica, se disfraza de necesidad la radical contingencia de la propia apuesta metafilosófica, bajo la forma de una petitio principii: dar por sentado "lo que, en todo caso, exigiría una demostración a partir de algún punto indiscutido" ${ }^{18}$. Rechazar la contingencia "conduce a buscar fuera, en la mente de Dios, en las leyes de la Naturaleza, en las leyes económicas de la Historia, en las reglas del Método Científico, o en los presupuestos regulativos de la Comunicación Trascendental, etc., una conexión necesaria que, operando de 'confort metafísico', permita conjurar la contingencia del tiempo y su azarosidad..." ${ }^{19}$. Por eso en su caracterización del pragmatismo Rorty lo visualiza sencillamente como la aplicación del antiesencialismo a nociones como "verdad", "conocimiento", "lenguaje", "moralidad" y otros objetos de especulación filosófica de índole similar ${ }^{20}$.

Tal como previene W. V. O. Quine: "Cuando con Dewey volvemos a una visión naturalista del lenguaje y una visión conductista del significado, lo que rechazamos no es solamente la figura de museo.

16. DAVIDSON, Donald: Subjetivo, intersubjetivo, objetivo (traducción de Olga Fernández Prat, $1^{a}$ edición). Ediciones Cátedra (Grupo Anaya S.A.), Madrid, 2003, pp. 250-251.

17. RORTY, Richard: Objetividad, relativismo y verdad, cit., p. 15.

18. BELLO REGUERA, Gabriel: Introducción. Richard Rorty en la encrucijada de la filosofía postanalítica: entre pragmatismo y hermenéutica. En: El giro lingüistico, Richard Rorty (traducción de Gabriel Bello, $1^{a}$ reimpresión). PAIDÓS Ibérica S.A., Barcelona, 1998, p. 19.

19. Íd., p. 20.

20. RORTY, Richard: Consecuencias del pragmatismo, cit., p. 243. 
Rechazamos una cierta seguridad de determinación... Cuando, por otra parte, reconocemos con Dewey que 'el significado... es primariamente una propiedad de la conducta', reconocemos que no hay significados, ni semejanzas ni distinciones de significados, más allá de las que están implícitas en las disposiciones de la gente a la conducta manifiesta" ${ }^{21}$. $\mathrm{Al}$ considerar el lenguaje de modo naturalista la noción de identidad de significado se nos muestra simplemente como un sinsentido ${ }^{22}$.

De partida es oportuno salvar una perogrullada. El antirrepresentacionalismo rortiano no duda de que la mayor parte de las cosas del universo son causalmente independientes del sujeto, sino de que lo sean representacionalmente. Así, que $\mathrm{X}$ sea representacionalmente independiente significa que $\mathrm{X}$ tiene un rasgo intrínseco tal (que posee bajo todas y cada una de sus descripciones posibles) que determina que sea mejor descrito por algunos términos que por otros. Pero como no sabemos cómo decidir acerca de qué descripciones de un objeto logran llegar a lo que le es intrínseco, por oposición a sus caracteres extrínsecos o meramente relacionales, se propone desechar la distinción intrínseco/ extrínseco y, por ende, la tesis de que las creencias representan y, asimismo, la noción de dependencia o independencia representacional ${ }^{23}$. Cuando un holista como Rorty pregunta por el significado de intrínseco se ve transportado a un círculo: si las propiedades intrínsecas son aquellas (y sólo aquellas) de las que nunca nadie se exime, entonces se trata de propiedades que las cosas tienen independientemente de lo que sepamos sobre cómo describirlas en el lenguaje. Este círculo es el único aceptable por el pensamiento rortiano, para el que la identidad es siempre “identidad bajo una descripción” ${ }^{24}$. Aunque con ciertos matices, Hilary

21. QUINE, Willard Van Orman: La relatividad ontológica y otros ensayos (traducción de Manuel Garrido y Josep Ll. Blasco, $1^{a}$ edición-2a reimpresión). Editorial TECNOS (Grupo Anaya S.A.), Madrid, 2002, p. 46.

22. Íd., p. 47.

23. RORTY, Richard: Verdad y progreso (traducción de Ángel Manuel Faerna GarcíaBermejo). PAIDÓS Ibérica S.A., Barcelona, 2000, p. 118.

24. Íd., p. 139.

Facultad de Derecho y Ciencias Sociales - Universidad de Valparaíso - Chile 
Putnam expresa una opinión coincidente en cuanto considera un factum que las palabras y las oraciones en un lenguaje carecen de significado intrínseco: "las palabras 'la nieve es blanca' — dice- podrían haber significado 'el carburador está obstruido' si la historia de nuestro idioma hubiese sido diferente" ${ }^{25}$. La verdad es un asunto vinculado con la utilidad de las creencias, no de relación entre piezas del mundo y piezas del lenguaje. Si la conciencia del mundo es un asunto lingüístico, entonces la filosofía es una discusión en torno a la utilidad y compatibilidad de las creencias. Más precisamente, una discusión acerca de los diferentes vocabularios en los que las creencias están formuladas. "No hay — según Rorty_ ninguna autoridad a la que apelar para legitimar el uso de un vocabulario fuera de la conveniencia para los propósitos humanos" ${ }^{26}$. Adoptando un derrotero similar, Peter F. Strawson abogó por el provecho de reconocer "cierta relatividad última en nuestra concepción de lo real; en este caso, la relatividad de las propiedades reales de los objetos físicos" ${ }^{27}$.

Hoy, dirá Rorty, el lenguaje ha sustituido a la mente como aquello que, supuestamente, está frente a la "realidad". Lo anterior desplaza la discusión de si la realidad material depende de la mente a preguntas sobre qué tipos de enunciados verdaderos — si existen- están en relación representacional con elementos no lingüísticos. Para el antirrepresentacionalista a menos que participemos en determinadas prácticas sociales, no habrá enunciados susceptibles de ser llamados "verdaderos" o "falsos". Los antirrepresentacionalistas sugieren desechar toda la serie de conceptos (por ejemplo, "cuestión de hecho") que se utiliza para inducir la idea de que entendemos el significado de "la determinación de la realidad". Esta serie es prescindible porque no se divisa cómo formular una prueba independiente de la exactitud de la representación, esto es, de la referencia o correspondencia a una realidad

25. PUTNAM, Hilary: Sentido, sinsentido y los sentidos (traducción de Norma B. Goethe). PAIDÓS Ibérica S.A., Barcelona, 2000, pp. 104-105.

26. RORTY, Richard: Verdad y progreso, cit., p. 169.

27. STRAWSON, Peter F.: Escepticismo y naturalismo: algunas variedades (traducción de Susana Badiola). A. Machado Libros S.A., Madrid, 2003, p. 96.

Revista de Ciencias Sociales - Número 65 (2014) - Universidad de Valparáíso - ISSN 0716-7725-Valparáiso, Chile 
determinada de forma antecedente, ninguna prueba distinta "del éxito que supuestamente se explica por esta exactitud" ${ }^{28}$.

Enseguida afirma: "Esta idea de que no hay una prueba de exactitud de la correspondencia independiente es el núcleo del argumento de Putnam según el cual nociones como 'referencia' —nociones semánticas que relacionan el lenguaje con el no lenguajeson internas a nuestra concepción general del mundo. Según Putnam, el intento de los representacionalistas de explicar el éxito de la astrofísica y el fracaso de la astrología está condenado a ser meramente un cumplido vacío a menos que alcancemos lo que denomina la perspectiva de Dios..." ${ }^{29}$. Cabe recordar que en ocasiones Putnam llama también al punto de vista del ojo de Dios como la "teoría perfecta", la "descripción verdadera", "el punto de vista de ninguna parte": la idea de verdad como correspondencia presupuesta en estas expresiones incluye aquellas características de unicidad, bivalencia e independencia que se predican del "realismo metafísico", para el cual la realidad dicta la totalidad de las descripciones verdaderas, la totalidad que representa la imagen de la realidad ${ }^{30}$. El realismo metafísico se hace de este modo metafísico al presuponer una concepción de la verdad como propiedad sustantiva: se trata de algo que trascendería la mera afirmación del enunciado cuando se dice de un enunciado particular que es verdadero. "Pero el deflacionista tiene razón al insistir que afirmar 'es verdadero que $p$ ' no es otra cosa que afirmar simplemente $p$ " ${ }^{31}$. El planteamiento strawsoniano discurre en el mismo sentido. Para Peter F. Strawson - que según Susana Badiola procuró conciliar el naturalismo de Wittgenstein y el realismo empirista de $\mathrm{Kant}^{32}$ — no existe un punto de

28. RORTY, Richard: Objetividad, relativismo y verdad, cit., pp. 16 y 19-21.

29. Íd., p. 22.

30. GOETHE, Norma B.: Introducción: Putnam y la lectura de los modernos. En: Sentido, sinsentido y los sentidos (traducción de Norma B. Goethe). PAIDÓS Ibérica S.A., Barcelona, 2000, p. 20, nota 10.

31. PUTNAM, Hilary: Sentido, sinsentido y los sentidos, cit., pp. 117-118.

32. BADIOLA, Susana: Introducción. El naturalismo filosófico de P.F. Strawson: inevitabilidad natural y aceptabilidad metafísica. En: Escepticismo y naturalismo: algunas variedades (traducción de Susana Badiola). A. Machado Libros S.A., Madrid, 2003, pp. 9 y ss.

Facultad de Derecho y Ciencias Sociales - Universidad de Valparaíso - Chile 
vista privilegiado desde el que nos sea posible considerar la totalidad de nuestros sistemas de creencias ${ }^{33}$.

Es imposible que una persona adopte una perspectiva superior para comparar esquemas conceptuales desprendiéndose temporalmente del suyo propio ${ }^{34}$. Davidson, en su objeción a una teoría de la verdad como correspondencia y luego de destacar que Rorty ha insistido en que la verdad como correspondencia transforma en inútil al concepto de verdad, postula que - para hacer frente al objetivista que replica que la verdad es independiente de nuestras creencias o de nuestras capacidades para llegar a ella - la objeción real que puede formularse a una teoría tal radica en que no hay nada con lo que puedan corresponderse las oraciones. Si toda oración, arguye, es relativa a un marco de referencia, el cual presumiblemente tiene que ser incluido en aquello con lo que se corresponda una oración verdadera, y si las oraciones verdaderas se corresponden con alguna cosa, entonces la conclusión es que esa cosa ha de ser el universo como un todo, y, en consecuencia, todas las oraciones verdaderas se corresponden con la misma cosa. Esto trivializa el concepto de correspondencia ${ }^{35}$.

De manera que, en opinión de Davidson, la objeción correcta contra las teorías de la correspondencia no es que la verdad no sea algo que podamos anhelar legítimamente, sino que tales teorías no proporcionan entidades con las que pueda decirse que se corresponden los enunciados o "vehículos de la verdad”. Nada hace que los enunciados sean verdaderos ${ }^{36}$. Es a partir de su crítica al dualismo esquema/ contenido que es posible atribuir a Davidson una postura antirrealista:

33. STRAWSON, Peter F.: Escepticismo y naturalismo: algunas variedades, cit., pp. 87-88.

34. RORTY, Richard: Objetividad, relativismo y verdad, cit., p. 22.

35. DAVIDSON, Donald: Subjetivo, intersubjetivo, objetivo, cit., pp. 253-254.

36. DAVIDSON, Donald: Subjetivo, intersubjetivo, objetivo, cit., pp. 254-255; De la verdad y de la interpretación. Fundamentales contribuciones a la filosofía del lenguaje (traducción de Guido Filippi, $2^{a}$ reimpresión). Editorial GEDISA S.A., Barcelona, 2001, pp. 21 y 57-72.

Revista de Ciencias Sociales - Número 65 (2014) - Universidad de Valparáíso - ISSN 0716-7725-Valparaíso, Chile 
según William Duica tal crítica, por una parte, recoge la idea de que la identificación de un hecho del mundo está indefectiblemente asociada a la identificación de un anunciado verdadero y, por otra, conduce a la afirmación de que no hay hechos no interpretados (esto es, una realidad independiente), o que la noción de "hecho" por fuera del lenguaje es ininteligible ${ }^{37}$. Habría aquí — según la acotación de Putnam — un falso dilema que obliga a optar entre el realismo metafísico o el refugio del antirrealismo: siendo éste la simple negación de la posición que se rechaza existe el riesgo de que no sea más que una forma de relativismo que sólo sustituye el "mito de lo dado" por el "mito de las prácticas comunitarias" 38 . Sin embargo a Putnam mismo, por intentar un derrotero intermedio (el llamado realismo interno), se le reprocha su permanente ambivalencia entre la perspectiva de la reflexión metateórica y la perspectiva científica ${ }^{39}$, a despecho de la explícita pretensión de este autor de "hacerle justicia al sentido en que nuestras afirmaciones epistémicas responden por la realidad sin buscar refugio en la fantasía metafísica" ${ }^{40}$.

Brevemente, el realismo interno niega no sólo que tenga sentido la noción de una realidad estructurada con independencia de los sujetos que hablan sobre ella, sino también que tenga sentido pensar en la verdad como determinada por esa realidad en sí misma: en una apelación al "sentido común" Putnam propone encontrar puntos de vista que permitan comprender los fenómenos desde nuestro mundo y

37. DUICA, William: Acerca del debate realismo-antirrealismo. En: Revista Ideas y Valores $\mathrm{N}^{\circ}$ 120, Universidad Nacional de Colombia, diciembre de 2002, Bogotá, p. 111.

38. GOETHE, Norma: Introducción. Putnam y la lectura de los modernos, cit., p. 25.

39. GOETHE, Norma: ob. cit., p. 37; QUINTANILLA, Miguel Ángel: Introducción: El realismo necesario. En: Las mil caras del realismo, Hilary Putnam (traducción de Margarita Vázquez Campos y Antonio Liz Gutiérrez, $1^{a}$ edición). PAIDÓS Ibérica S.A., Barcelona, 1994, pp. 31-33.

40. PUTNAM, Hilary: Sentido, sinsentido y los sentidos, cit., p. 48.

Facultad de Derecho y Ciencias Sociales - Universidad de Valparaíso - Chile 
nuestra práctica ${ }^{41}$. Admite no obstante Putnam que ya sea en ciencia o en ética lo que se tienen son máximas, no algoritmos; y las máximas requieren interpretación contextual. Esto muestra que en la concepción pragmatista desde la partida estuvo presente el problema de la subjetividad y de la intersubjetividad. Ningún ser humano en solitario puede alcanzar otro tipo de certeza que no sea aquella teñida de subjetividad, cuando intenta interpretar las máximas para sí mismo de manera refractaria a la crítica de otros referida a cómo las interpreta. "Incluso - dice Putnam - la noción de 'verdad' no tiene sentido en tal 'soledad moral' ya que 'la verdad presupone un estándar externo al pensador"' ${ }^{42}$. La prueba de las nuevas ideas requiere cooperación para colocarse a cubierto de la posibilidad de considerar solamente ideas que reflejan los prejuicios que uno se ha formado ${ }^{43}$. La preocupación que para Putnam tiene ribetes genuinos radica en que los enunciados acerca de una realidad externa no pueden ser verdaderos o falsos en ausencia de conexiones justificativas entre las cosas que decimos mediante el lenguaje y algún aspecto de esa realidad: "[porque] si nuestro único modelo del lenguaje es el de un esquema cerrado respecto de las relaciones de justificación, un esquema en el que literalmente nada se extiende fuera del lenguaje..., entonces no seríamos afectados hasta el punto de concebir de qué modo podríamos ser hablantes o intérpretes, y mucho menos estaríamos en condiciones de concebir la forma en que podríamos ser intérpretes omniscientes" ${ }^{\prime 4}$.

Michael Dummett, sin ánimo de resolver las disputas entre realistas y antirrealistas, señala preferir como forma de caracterizar a

41. LIZ, Manuel: Introducción. En: La herencia del pragmatismo, Hilary Putnam (traducción de Manuel Liz y Margarita Vázquez, $1^{a}$ edición). PAIDÓS Ibérica S.A., Barcelona, 1997, pp. 9-11.

42. PUTNAM, Hilary: La herencia del pragmatismo (traducción de Manuel Liz y Margarita Vázquez, $1^{a}$ edición). PAIDÓS Ibérica S.A., Barcelona, 1997, 181.

43. Íd., pp. 181-182.

44. PUTNAM, Hilary: El pragmatismo. Un debate abierto (traducción de Roberto Rosaspini Reynolds, $1^{a}$ edición-1 $1^{a}$ reimpresión). Editorial GEDISA S.A., Barcelona, 2006, pp. 96-97.

Revista de Ciencias Sociales - Número 65 (2014) - Universidad de Valparáíso - ISSN 0716-7725-Valparáiso, Chile 
esta querella (si bien, según confiesa, puede que no sea una caracterización lo suficientemente explicativa ni precisa) no como el debate concerniente a una clase de entidades, o a una clase de términos, sino a una clase de enunciados, que pueden ser enunciados acerca del mundo físico, enunciados de eventos, procesos o estados mentales y enunciados matemáticos, entre otros. A dicha clase de enunciados Dummett la denomina "la clase en disputa" ${ }^{45}$. A la luz de esta categorización Dummett describe al realismo como la creencia de que los enunciados de la clase en disputa poseen un valor de verdad objetivo, independiente de nuestros medios para conocerlo. El antirrealista - prosigue Dummett- opone a tal manera de ver el asunto que los enunciados de la clase en disputa se entienden sólo con referencia a la clase de cosas que consideramos como evidencia para los enunciados de esta clase. Así, mientras el realista afirma que los significados de los enunciados de la clase en disputa no están relacionados directamente con el tipo de evidencia que se tenga para ellos, los antirrealistas sostienen que los significados de estos enunciados están directamente ligados con lo que tomamos como su evidencia. La conclusión de Dummett es que estamos ante una disputa sobre la clase de significado que tienen los enunciados ${ }^{46}$.

El realista metafísico — comenta Norma Goethe- a veces postula "poderes mágicos" para captar la imagen "idealizada" de la realidad $^{47}$. El comentario es pertinente si se piensa en los supuestos metafísicos del realismo tradicional que Putnam identifica, a saber: (1) existe una totalidad definida de todos los objetos susceptibles de clasificación y a los que las afirmaciones epistémicas pueden referirse, así como una totalidad definida y fija de todas las propiedades (incluidas relaciones), formas o universales; (2) todo significado posible de una

45. DUMMETT, Michael: La verdad y otros enigmas (traducción de Alfredo Herrera Patiño). Fondo de Cultura Económica S.A de C.V., México D.F., 1990, pp. 220-221.

46. Íd. ibíd.

47. GOETHE, Norma: Introducción: Putnam y la lectura de los modernos, cit., p. 29.

Facultad de Derecho y Ciencias Sociales - Universidad de Valparaíso - Chile 
palabra se corresponde con una de dichas propiedades, formas o universales; (3) hay una totalidad definida de todas las afirmaciones epistémicas posibles fijas de una vez y para siempre independientemente de los sujetos epistémicos o usuarios del lenguaje ${ }^{48}$. Parafraseando a Dewey, puede decirse que el problema medular del realismo metafísico es el de intentar construir sistemática e inútilmente sobre la noción de un universo estático ${ }^{49}$.

Una vez denunciada la imposibilidad de acceso a la Verdad y la ineficacia de un cometido semejante, a título prospectivo, dice Bello, para Rorty dos distinciones marcarán un posible futuro de la filosofía: por una parte, la distinción entre "filosofía como propuesta" de figuras de significado y valor contingentes; por otra, la distinción entre "describir" y "cambiar" la mente. La primera conlleva descubrir y desconstruir el vocabulario filosóficamente fundacional que sirve de Espejo de la mente para que ésta pueda funcionar como Espejo de la Naturaleza (supuesto epistemológico básico). La segunda implica transformar el lenguaje para acercarse a la poética, el juego estético y una ética desfundada y desfundante ${ }^{50}$. "En este contexto los conceptos de 'edificación' y 'conversación' sustituyen sistemáticamente a los de 'conocimiento' e 'investigación', cuyo significado es la desconstrucción de la relación jerárquica entre la perspectiva epistémica y la perspectiva moral, con la consiguiente liberación o desfundamentación de la última" ${ }^{51}$. Cabe consignar que probablemente Rorty no estaría de acuerdo en calificar su obra como derridianamente desconstructiva si nos atenemos a estas palabras: "Los fans [de Derrida] piensan también que existe un método llamado 'desconstrucción' que puede aplicarse a los textos y enseñarse a los estudiantes. Jamás fui capaz de entender de qué se trata este método ni tampoco lo que se estaba enseñando a los

\footnotetext{
48. PUTNAM, Hilary: Sentido, sinsentido y los sentidos, cit., pp. 51 y ss.

49. DEWEY, John: La miseria de la epistemología, cit., p. 159.

50. BELLO REGUERA, Gabriel: Introducción. Richard Rorty en la encrucijada..., cit., pp. 20-21.

51. Íd., p. 21.
}

Revista de Ciencias Sociales - Número 65 (2014) - Universidad de Valparáíso - ISSN 0716-7725-Valparaíso, Chile 
alumnos... Jamás he encontrado, ni he sido capaz de inventar, una definición satisfactoria de esta palabra”, para concluir que la usa con culposa distracción ${ }^{52}$.

El pensamiento rortiano efectúa un giro pragmatista destinado a referir toda justificación, tanto epistémica como moral, a las prácticas sociales (contingentes), y a disolver la idea de autoridad y racionalidad de la epistemología como fundamento-sede de la necesidad de toda justificación posible ${ }^{53}$. Es relevante advertir que la posición que adopta Rorty, para ponerse a cubierto de los ataques de cinismo que se le imputan, exigiría a sus detractores demostrar que "moral" y "moral fundada" son sinónimos, lo cual hasta ahora no ha sucedido ${ }^{54}$. De este modo lo que Rorty desconstruye es la codificación moral implícita en lo que Derrida llamó la "metafísica de la presencia”, esto es, la tendencia a presentar las cosas como si la opción por la necesidad fundante fuera más racional, más filosófica, más seria, más moral o más humana que la opción por la contingencia. Y, al contrario, como si la opción por la contingencia fuera irracional y, acaso, inmoral ${ }^{55}$. En opinión de Bello, presentar las cosas de esta última manera es un claro ejemplo de dictadura moral resultado de una "previa apropiación privada de una competencia metaaxiológica" indigna ${ }^{56}$.

Podría eliminarse la tendencia a exacerbar el intento por situarse fuera de las necesidades humanas y el afán por la verdad mediante una educación moral adecuada, destinada a sublimar el deseo de estar en "relaciones adecuadamente humildes con realidades no humanas" en el deseo de "encuentros libres y abiertos entre seres humanos", que

52. RORTY, Richard: Notas sobre desconstrucción y pragmatismo. En: Desconstrucción y pragmatismo. Compilación de Chantal Mouffe (traducción de Carlos Mayer, $1^{a}$ edición). PAIDÓS SAICF, Buenos Aires, 1998b, pp. 38-39.

53. BELLO REGUERA, Gabriel: Introducción. Richard Rorty en la encrucijada..., cit., p. 22.

54. Íd., pp. 21-22, nota 14 .

55. Íd., p. 24.

56. Íd. ibíd., nota 18.

Facultad de Derecho y Ciencias Sociales - Universidad de Valparaíso - Chile 
culminan o en el acuerdo intersubjetivo o en la tolerancia recíproca ${ }^{57}$. En sintonía con lo dicho Rorty recoge la sugerencia davidsoniana de desechar la distinción esquema/contenido, esto es, la distinción entre realidades determinadas y un conjunto de palabras o conceptos que pueden ser o no adecuados a ellos, porque genera un innecesario conflicto entre relativismo versus absolutismo (el debate concerniente a si el conocimiento es relativo a las perspectivas y sus peculiaridades o si está en contacto con la identidad y la diferencia objetivas de la naturaleza). Desechar esta distinción implica abandonar la idea de que las creencias representan un contenido conforme a las convenciones de un esquema ${ }^{58}$. En este orden de ideas Ruth Anna Putnam trae a colación la profunda desconfianza de Dewey hacia las hipótesis a gran escala, convencido de que ellas siempre se formulan como universales en lugar de históricamente limitadas, o como normativas en lugar de descriptivas, y son empleadas no para dirigir la selección de los datos, sino para prejuzgarlos $^{59}$.

La reflexión davidsoniana acerca de lo que sea una creencia no consiste en un análisis de la representación, sino en un estudio relativo a cómo un usuario del lenguaje interactúa con el ambiente ${ }^{60}$. El punto de partida es darwiniano: las creencias son adaptaciones al entorno y no cuasi-imágenes. Como comenta Rorty "[Davidson estima que] las creencias son hábitos de actuar en vez de partes de un 'modelo' del mundo"61. De esta manera Rorty suscribirá la idea, de raigambre davidsoniana, de que no tiene sentido concebir la realidad como es en sí, haciendo abstracción de la forma en que se representa en el juicio

\footnotetext{
57. RORTY, Richard: Objetividad, relativismo y verdad, cit., p. 24.

58. Íd., p. 25.

59. PUTNAM, Ruth Anna: La lógica de Dewey: Epistemología como hipótesis. En: La herencia del pragmatismo, Hilary Putnam (traducción de Manuel Liz y Margarita Vázquez, $1^{a}$ edición). PAIDÓS Ibérica S.A., Barcelona, 1997, p. 234.

60. RORTY, Richard: Objetividad, relativismo y verdad, cit., p. 26.

61. Íd. ibíd.
}

Revista de Ciencias Sociales - Número 65 (2014) - Universidad de Valparáíso - ISSN 0716-7725-Valparaíso, Chile 
humano ${ }^{62}$. La noción de "relaciones de hecho independientes de la teoría e independientes del lenguaje" constituye una petición de principio: no sería posible contrastar el mundo con aquello con lo que se conoce el mundo, pues ello sugiere haber logrado salir fuera de nuestra mente. Los antirrepresentacionalistas rechazan "la imagen cartesiano-kantiana que presupone la idea de 'nuestras mentes' o 'nuestro lenguaje' como un 'interior' que pueda contrastarse con algo (quizás algo muy diferente) 'exterior'. Desde un punto de vista darwiniano, simplemente no hay manera de dar sentido a la idea de que nuestra mente o nuestro lenguaje estén sistemáticamente fuera de sintonía con lo que está más allá de nuestra piel" ${ }^{63}$. Rorty resumió así su diagnóstico del cartesianismo: pide certezas imposibles, su solipsismo metodológico se traduce en exigir "que uno mismo lo haga todo, una exigencia imposible de cumplir" ${ }^{64}$.

Conviene tener presente que la influencia darwiniana sobre el pensamiento pragmatista y antirrepresentacionalista fue, en cierto modo, inevitable ${ }^{65}$. Davidson apunta que "el fracaso de las teorías de la correspondencia de la verdad basadas en la noción de hecho puede remontarse a una fuente común: el deseo de incluir en la entidad a la cual corresponde una oración verdadera no sólo los objetos 'acerca de los cuales' es la oración (otra idea llena de problemas) sino también toda cosa que la oración diga acerca de ellos", y agrega que como consecuencia de esto, por una parte, se hace difícil describir el hecho que verifica una oración excepto mediante el uso de la propia oración y, por otra, la relación de correspondencia sólo se aplicaría en forma directa tratándose de las oraciones más simples ${ }^{66}$.

Un aspecto central del pensamiento rortiano afirma que por más beneficiosas que hayan sido las ideas de "objetividad" y "trascendencia"
62. Íd., p. 28.
63. Íd., p. 29.
64. RORTY, Richard: Consecuencias del pragmatismo, cit., p. 267.
65. DEWEY, John: La miseria de la epistemología, cit., p. 49.
66. DAVIDSON, Donald: De la verdad y de la interpretación..., cit., p. 68.

Facultad de Derecho y Ciencias Sociales - Universidad de Valparaíso - Chile 
en nuestra cultura, idéntico resultado podría alcanzarse con la idea de comunidad que procura el consenso intersubjetivo y la novedad (una comunidad que Rorty visualiza de carácter democrática, progresista y pluralista). Al reinterpretar la objetividad como intersubjetividad, o como solidaridad, es posible desechar la cuestión de cómo contactarse con una "realidad independiente de la mente e independiente del lenguaje". Esta querella se remplazaría por preguntas sobre los límites de nuestra comunidad o el grado de libertad y apertura de nuestros encuentros, o por interrogantes relativas a si nuestras conquistas solidarias han sido alcanzadas al precio de excluir, postergar o silenciar a quienes sufren y pertenecen a otras culturas. Estas preguntas, que son más políticas que metafísicas o epistemológicas, nos colocan — dirá Rorty - en la senda correcta al concebir el pragmatismo "no como el fundamento, sino como la forma de despejar el camino para la política democrática" ${ }^{67}$. Ello porque son necesidades reales (y reconocerlas una exigencia filosófica) la necesidad de un conocimiento convalidado intersubjetivamente, la necesidad de tolerancia y la necesidad de formas de vida basadas en la responsabilidad existencial ${ }^{68}$.

\section{La función de enlace del etnocentrismo rortiano}

Rorty utiliza la idea de etnocentrismo como enlace entre el antirrepresentacionalismo y el liberalismo político ${ }^{69}$. A juicio de Bello, el etnocentrismo rortiano constituiría un intento de construir el punto de vista propio como situado sociohistóricamente, por lo que debe tenerse sólo como un punto de vista al igual que cualquier otro, y no como una "mirada de Ojo de Dios" ${ }^{70}$. Lo anterior obedece a que una consecuencia del antirrepresentacionalismo es el reconocimiento de que

\footnotetext{
67. RORTY, Richard: Objetividad, relativismo y verdad, cit., p. 30.

68. PUTNAM, Hilary: El pragmatismo. Un debate abierto, cit., p. 108.

69. RORTY, Richard: Objetividad..., cit., p. 16.

70. BELLO REGUERA, Gabriel: Introducción. Richard Rorty en la encrucijada..., cit., p. 28, nota 22 .
}

Revista de Ciencias Sociales - Número 65 (2014) - Universidad de Valparáíso - ISSN 0716-7725-Valparáiso, Chile 
"ninguna descripción de la forma de ser de las cosas desde la perspectiva de Dios, ningún anclaje celestial ofrecido por una ciencia actual o por surgir" puede liberarnos de la contingencia del modo en que hemos sido aculturados ${ }^{71}$. Pero es posible, en opinión de Rorty, superar positivamente nuestra aculturación: mediante la educación en una cultura orgullosa de no ser monolítica, esto es, de su tolerancia "a la pluralidad de subculturas y de su disposición a escuchar a las culturas vecinas" 72 . El etnocentrismo es una condición de la que no podemos huir, más o menos sinónimo a "finitud humana", que no puede interpretarse en Rorty como necesariamente equivalente a la lealtad acérrima que pueda profesarse a una determinada cultura sociopolítica. En los hechos Rorty deplora esta asimilación, aunque luego se declare tributario del liberalismo político ${ }^{73}$. Cabría precisar que tampoco nuestro autor admite la sugerencia de tratar toda cultura como una obra de arte digna de preservación prima facie. A su juicio es éste un intento de dar continuidad a la noción kantiana de "dignidad humana", incluso cuando se ha abandonado la racionalidad entendida como ese ingrediente extra y añadido que poseen exclusivamente los seres humanos y que se articula en función de fines distintos a la mera supervivencia (la racionalidad sería algo así como la capacidad de establecer una jerarquía evaluativa, en lugar de limitarse al simple ajuste medios a fines). Esta actitud recrea la distinción kantiana entre valor y dignidad basada en la creencia de que toda cultura humana posee un valor inconmensurable ${ }^{74}$, lo que suscita dudas en el filósofo cuando el argumento se utiliza para exaltar lo no occidental y a los oprimidos como algo per se más valioso que todo lo realizado por el "occidente contemporáneo" 75 . Rorty aquí no se erige en adalid del liberalismo

\footnotetext{
71. RORTY, Objetividad..., cit., p. 31.

72. Íd. ibíd.

73. Íd., p. 33, en especial nota 29.

74. RORTY, Richard: Pragmatismo y política (traducción de Rafael del Águila, $1^{a}$ edición). PAIDÓS Ibérica S.A., Barcelona, 1998a, pp. 81 y 86.

75. Íd., p. 87.
}

Facultad de Derecho y Ciencias Sociales - Universidad de Valparaíso - Chile 
occidental, sino que meramente intenta prevenir acerca de la tentación de privilegiar unas culturas por sobre otras por apelación a sus condiciones de vida o a su historia de humillaciones: en toda comunidad el sufrimiento es una constante.

El planteamiento que sustenta la idea de la filosofía de constituirse en fundamento respecto del resto de la cultura y, por ende, su intento de confirmar o desacreditar las pretensiones de conocimiento que se hallan en la ciencia, en la moralidad, en el arte o en la religión, nace de su autodefinición como disciplina que comprende los fundamentos del conocimiento. Estos fundamentos los encuentra la filosofía en un estudio del "hombre en cuanto ser que conoce", o en una investigación acerca de los "procesos mentales" o de la "actividad de representación" que posibilitan el conocimiento" . "Saber es representar con precisión lo que hay fuera de la mente; entender de esta manera la posibilidad y naturaleza del conocimiento es entender la forma en que la mente es capaz de reconstruir tales representaciones" $"$. En ese marco la filosofía pasa a ser una teoría general de la representación. Rorty recuerda que así como la "teoría del conocimiento" basada en una comprensión de los "procesos mentales" se origina en el siglo XVII, en especial en los escritos de Locke; la de la "mente" como entidad en la que ocurren tales procesos surge, en ese mismo período, en la obra de Descartes. Algo más tarde, hacia el siglo XVIII, merced a las tesis de Kant, aparece la idea de la filosofía como tribunal de la "razón pura" que confirma o rechaza las pretensiones del resto de la cultura $^{78}$. Sin embargo, advierte Rorty, ya en el siglo XX con el triunfo de la secularización sobre las reivindicaciones de la religión el filósofo deja de ocupar la vanguardia intelectual y pierde su rol tutelar ante la superstición. Como consecuencia, la filosofía (liada en sus esfuerzos de cientificidad y rigor) se alejó del resto de la cultura, y sus discusiones

76. RORTY, Richard: La filosofía y el espejo de la naturaleza (traducción de Jesús Fernández Zulaica, $6^{a}$ edición). Ediciones Cátedra (Grupo Anaya S.A.), Madrid, 2010, p. 13.

77. Íd. ibíd.

78. Íd., pp. 13-14.

Revista de Ciencias Sociales - Número 65 (2014) - Universidad de Valparáíso - ISSN 0716-7725-Valparáiso, Chile 
analíticas y fenomenológicas destinadas a fundamentar y a criticar comenzaron a verse absurdas y aisladas ${ }^{79}$.

En ese estado de cosas, Rorty destaca los aportes de Wittgenstein en aras de una nueva teoría de la representación que no se relacionara con el mentalismo; de Heidegger por un nuevo conjunto de categorías filosóficas abstraídas de la ciencia, la epistemología o la certeza cartesiana, y de Dewey en pos de una visión naturalizada de la noción hegeliana de la historia ${ }^{80}$. Estos pensadores se emanciparon, según Rorty, de la concepción kantiana de la filosofía en cuanto disciplina básica, lo cual se revelaría en sus últimos escritos, caracterizados por ser más terapéuticos que constructivos, más edificantes que sistemáticos y dirigidos "a hacer que el lector se cuestione sus propios motivos para filosofar más que a presentarle un nuevo programa filosófico" ${ }^{81}$. Para Ángel Manuel Faerna el planteamiento de Dewey nos previene frente a un peligro doble: si es cierto que atar el pensamiento filosófico a un determinado tiempo y lugar puede conducirlo a perecer junto con ellos, también es cierto que no hacerlo puede implicar que nazca muerto sin haber sido de ayuda a sus contemporáneos cuando se trata de resolver los problemas que los aquejan. "A los filósofos — dice Faernanormalmente les cuesta aceptar la idea de que la filosofía no haya nacido para la eternidad, incluso después de haber aprendido que así es como sucede con todo lo demás" 82 .

Rorty afirma: "Wittgenstein, Heidegger y Dewey están de acuerdo en que hay que abandonar la noción del conocimiento en cuanto representación exacta, que resulta posible gracias a procesos mentales especiales e inteligible gracias a una teoría general de la representación. Los tres consideran que se deben descartar las nociones

79. Íd., pp. 14-15.

80. Íd., p. 15.

81. Íd. ibíd.

82. FAERNA, Ángel Manuel: Introducción. En: La miseria de la epistemología. Ensayos de pragmatismo, John Dewey (traducción de Ángel M. Faerna). Editorial Biblioteca Nueva S.L., Madrid, 2010, p. 24.

Facultad de Derecho y Ciencias Sociales - Universidad de Valparaíso - Chile 
de 'fundamentos del conocimiento' y de la filosofía en cuanto centrada en el intento cartesiano de dar respuesta al escéptico epistemológico. Además, prescinden de la idea de 'la mente' común a Descartes, Locke y Kant - en cuanto tema especial de estudio, situada en el espacio interior y dotada de elementos o procesos que posibilitan el conocimiento. Esto no quiere decir que tengan otras 'teorías del conocimiento' o 'filosofías de la mente'. Rechazan la epistemología y la metafísica en cuanto disciplinas posibles" ${ }^{83}$. La tradición de DescartesLocke-Kant se articula en torno a la idea de que la actividad humana y la investigación, la búsqueda del conocimiento, se verifica dentro de un marco que sería susceptible de aislar antes de la conclusión de la investigación, esto es, un conjunto de presuposiciones que podrían descubrirse a priori. En opinión de Rorty, la existencia de ese marco sólo tiene sentido si se considera que ha sido impuesto por la naturaleza del sujeto que conoce, por la naturaleza de sus facultades o por la naturaleza del medio dentro del cual actúa ${ }^{84}$. De otro modo: "La idea de que puede haber eso que se llama 'fundamentos del conocimiento' (de todo conocimiento - en todos los campos, del pasado, presente, futuro) o una 'teoría de la representación' (de toda representación, en los vocabularios conocidos y en los que ahora no podemos ni imaginar) depende de la suposición de que existe semejante constricción a priori" ${ }^{85}$. Una concepción deweyana del conocimiento que lo entienda como creencia justificada no limita aquello que pueda figurar como conocimiento, desde que la justificación es un fenómeno social y no una transacción entre el sujeto que conoce y "la realidad". Una concepción wittgensteiniana del lenguaje que lo considera instrumento y no espejo no necesita condiciones necesarias de posibilidad de la "representación lingüística". Una concepción heideggeriana advierte que el intento de transformar la naturaleza del sujeto que conoce en fuente de verdades necesarias es un ensayo desacertado de acudir a auxilio técnico en vez de una apertura a lo desconocido ${ }^{86}$.

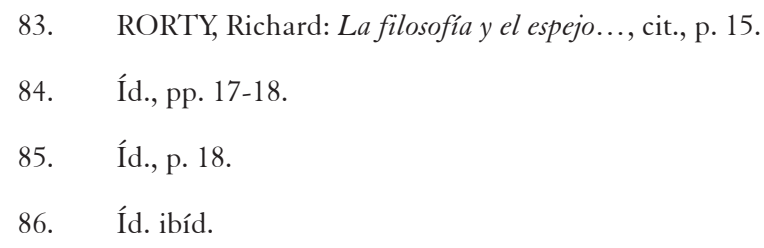

Revista de Ciencias Sociales - Número 65 (2014) - Universidad de Valparaíso - ISSN 0716-7725-Valparaíso, Chile 
La filosofía tradicional ha buscado escapar de la historia, a objeto de encontrar condiciones ahistóricas de cualquier posible cambio. Por el contrario, el mensaje de los autores citados precedentemente es edificantemente historicista, por emplear una expresión rortiana. Colocar las cosas en la perspectiva de estos pensadores permite ver la verdad no como la representación exacta de la realidad, sino como aquello en lo que es conveniente creer, en cuanto nos ayuda a hacer lo que queremos hacer ${ }^{87}$. De allí es que Rorty haya elegido el título "La filosofía y el espejo de la naturaleza" (Philosophy and the Mirror of Nature) para uno de sus trabajos medulares: lo que llamamos "la verdad" está constituido por imágenes más que proposiciones, metáforas más que afirmaciones, y es lo que configura la mayor parte de nuestras convicciones filosóficas. En alusión a Dewey, Rorty acota que éste luego de atacar las tradicionales imágenes del espejo postuló un nuevo tipo de sociedad, una sociedad ideal donde la cultura ya no está dominada por la pretensión del conocimiento objetivo sino del desarrollo estético ${ }^{88}$. En su naturalismo no reduccionista Strawson debería suscribir las palabras de Rorty, desde el momento en que él mismo admite que no hay razón para decir ni que la perspectiva científica objetiva ni que la perspectiva moral y perceptiva humana nos proporcione la concepción exclusivamente correcta de la naturaleza real de las cosas. "Sólo podríamos tener alguna razón de este tipo — dice Strawson- en caso de que pudiéramos adoptar un punto de vista superior a ambos. Pero no hay un punto de vista de estas características" ${ }^{89}$. Ello a despecho del platonista, para quien el significado de un enunciado está dado por la determinación de sus condiciones de verdad "concebidas [éstas] como determinadas independientemente de si podemos o no reconocer el valor de verdad del enunciado" ${ }^{00}$.

\footnotetext{
87. Íd., pp. 19-20.

88. Íd., p. 21.

89. STRAWSON, Peter F.: Escepticismo y naturalismo..., cit., p. 107.

90. DUMMETT, Michael: La verdad y otros enigmas, cit., p. 229.
}

Facultad de Derecho y Ciencias Sociales - Universidad de Valparaíso - Chile 
Como señala Gabriel Bello, la táctica de Rorty consiste en mostrar que lo que algunos pretenden que sólo es alcanzable mediante un fundamento capaz de cimentar una cadena de necesidad firme y segura, se puede lograr de otro modo ${ }^{91}$. Este "otro modo" importa justificar la propia tradición moral o la propia comunidad sociocultural de pertenencia, para lo cual bastaría la práctica de la conversación sobre el resto de las prácticas comunales, incluida la conversación misma. En procura de lo anterior el filósofo norteamericano se desmarca de la epistemología (conmensuración) e introduce lo que Bello denomina "hermenéutica convencional"92.

En la óptica davidsoniana la calificación de Bello sería acertada. Se trata de una hermenéutica convencional porque se desarrolla en la práctica de la conversación. Como afirma Davidson en una cita colmada de poesía: "La metáfora es el sueño del lenguaje y, como todo sueño, su interpretación refleja tanto del intérprete como del originador. La interpretación de los sueños requiere la colaboración entre una persona que sueña y una persona que está despierta, aun cuando sean la misma persona; y el acto de interpretación es en sí mismo una obra de la imaginación. Así también, la comprensión de una metáfora es un empeño tan creativo como la creación de una metáfora, y las reglas que

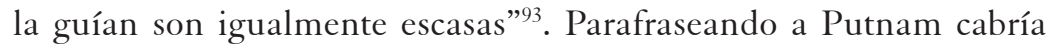
advertir que lo dicho no implica afirmar que cuestiones metodológicas y filosóficas que se estiman fundamentales y que se debaten con ocasión de los cambios de paradigmas científicos, sean cuestiones éticas. Lo que se postula es que son de valor, esto es, que la decisión referida "a todo aquello que consideramos como 'coherente' y lo que consideramos como 'outrée' es, en todo caso, un juicio de valor" "94. Que sea un juicio de valor es indudable si se piensa — con James- que una explicación

91. BELLO REGUERA, Gabriel: Introducción. Richard Rorty en la encrucijada..., cit., p. 27.

92. Íd. ibíd., en especial nota 20.

93. DAVIDSON, Donald: De la verdad y de la interpretación..., cit., p. 245.

94. PUTNAM, Hilary: El pragmatismo. Un debate abierto, cit., p. 31.

Revista de Ciencias Sociales - Número 65 (2014) - Universidad de Valparaíso - ISSN 0716-7725-Valparaíso, Chile 
outré que violara todas nuestras preconcepciones, nunca pasaría por verdadera concepción de una novedad. "Debemos ahondar afanosamente hasta que hallemos algo menos excéntrico... Una nueva verdad es siempre una especie de guión, un suavizador de transiciones" ${ }^{95}$.

Agrega William James: "La antigua opinión concordará con el nuevo hecho a condición de mostrar un mínimo de conmoción, un máximo de continuidad. Consideramos que una teoría es verdadera en proporción a su éxito para resolver este 'problema de máxima y mínima'. Pero el éxito en resolver este problema es, ante todo, cuestión de aproximación. Y decimos que tal teoría lo resuelve, en conjunto, más satisfactoriamente que tal otra, pero éste hace referencia a nosotros mismos y cada individuo subrayará diversamente sus preferencias. Hasta cierto punto, por lo tanto, todo es aquí plástico" ${ }^{” 6}$.

Rorty sostiene que el deseo de una teoría del conocimiento es un “deseo de constricción”, entendido como la esperanza de encontrar fundamentos a los que aferrarse, objetos que se impongan a sí mismos, representaciones "que no se puedan negar" ${ }^{97}$, porque el único criterio objetivo de realidad es la constricción a las confrontaciones del pensamiento ${ }^{98}$. La reacción en contra de este deseo de constricción, esto es, del deseo por hallar fundamentos y representaciones que no puedan ser rechazadas, es denominada por Rorty como "conductismo epistemológico", término que luego es reemplazado por "pragmatismo". El conductismo epistemológico no es una nueva y mejor manera de hacer epistemología, sino una renuncia al deseo de constricción y confrontación: cuando Rorty contrapone la epistemología (entendida en el sentido de búsqueda de fundamentos) a la "hermenéutica", lo que intenta es proponer una idea de conversación y esperanza que sustituya la noción de objetividad por la de intersubjetividad ${ }^{99}$. Cuando

95. JAMES, William: Pragmatismo, cit., p. 64.

96. Íd. ibíd.

97. RORTY, Richard: La filosofía y el espejo..., cit., p. 287.

98. PUTNAM, Hilary: El pragmatismo. Un debate abierto, cit., p. 26.

99. KALPOKAS, Daniel: Richard Rorty y la superación pragmatista de la epistemología (1 ${ }^{a}$ edición). Ediciones del Signo, Buenos Aires, 2005, pp. 36-37.

Facultad de Derecho y Ciencias Sociales - Universidad de Valparaíso - Chile 
nuestro autor se ocupa de la hermenéutica no pretende llenar la sensación de vacío que puede generar la desaparición de la epistemología, ni postular la hermenéutica como sucesora de la epistemología. En ese sentido la interpretación de "hermenéutica" que Rorty ofrece no es el nombre de una disciplina, ni de un método de conseguir los resultados que la epistemología no obtuvo, ni de un programa de investigación. "Por el contrario, la hermenéutica es una expresión de esperanza de que el espacio cultural dejado por el abandono de la epistemología no llegue a llenarse" ${ }^{100}$. Mientras la epistemología supone que todas las aportaciones a un discurso son conmensurables, la hermenéutica es una refutación de esta tesis ${ }^{101}$. Rorty entiende por "conmensurable" aquello que es capaz de someterse a un conjunto de reglas que prescriben cómo establecer un acuerdo respecto de lo que resolvería un problema en todos los puntos donde hay conflicto entre las afirmaciones. Estas reglas disponen cómo construir una situación ideal en la que todos los desacuerdos residuales deben considerarse "no cognitivos" o variables, o bien temporales cuando pueden ser resueltos haciendo algo más ${ }^{102}$. Para Rorty la "idea dominante de la epistemología es que para ser racional, para ser plenamente humano, para hacer lo que debemos, hemos de ser capaces de llegar a un acuerdo con otros seres humanos. Construir una epistemología es encontrar la máxima cantidad de terreno que se tiene en común con otros. La suposición de que se puede construir una epistemología es la suposición de que ese terreno existe" 103 .

Insinuar la inexistencia de este terreno común coloca en peligro la racionalidad, pero la sospecha de Rorty se dirige precisamente a la noción de la tradición cartesiano-kantiana de racionalidad. Es frente a ese vacío dejado por la epistemología que el filósofo se decanta por la hermenéutica. En opinión de Rorty la hermenéutica considera las

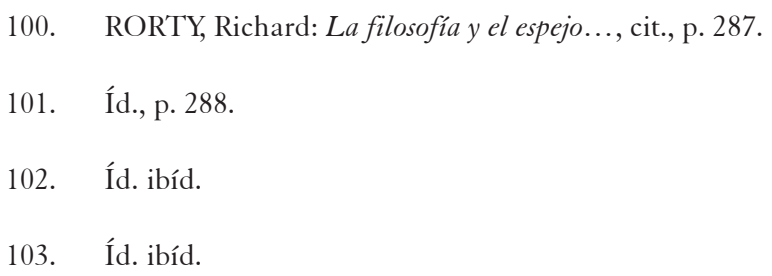


relaciones entre varios discursos como hilos dentro de una posible conversación (que no presupone ninguna matriz disciplinaria que una a los hablantes), en la que nunca se pierde la esperanza de llegar a un acuerdo mientras dure la conversación. Pero no se trata de "la esperanza en el descubrimiento de un terreno común existente con anterioridad, sino simplemente la esperanza de llegar a un acuerdo, o, cuando menos, a un desacuerdo interesante y fructífero" 104 . Situados en la hermenéutica como expresión de esperanza ante lo "inconmensurable" la racionalidad consiste en una disposición activa ante la alteridad: "Para la hermenéutica, ser racional es estar dispuesto a abstenerse de la epistemología — de pensar que haya un conjunto especial de términos en que deben ponerse todas las aportaciones a la conversación-y estar dispuesto a adquirir la jerga del interlocutor en vez de traducirla a la suya propia” 105 . En palabras de Rorty: "La epistemología ve a los participantes unidos en lo que Oakeshott llama una universitas - grupo unido por intereses mutuos en la consecución de un fin común. La hermenéutica los ve unidos en lo que él llama una societas - personas cuyos caminos por la vida se han juntado, unidas por la urbanidad más que por un objetivo común, y mucho menos por un terreno común"106. Appiah lo expresa en términos similares cuando refiriéndose a la idea de Walzer de que la moralidad es densa desde el inicio arguye que existiendo conceptos muy densos, que son característicos de sociedades particulares, el nivel más profundo de desacuerdo entre valores opuestos se da cuando una parte invoca un concepto del que la otra - lisa y llanamente- carece. Éste es el tipo de desacuerdo en el que - dice el filósofo ghanés - el desafío no consiste en acordar sino en comprender ${ }^{107}$.

\footnotetext{
104. Íd. ibíd.

105. Íd., p. 290.

106. Íd. ibíd.

107. APPIAH, Kwame Anthony: Cosmopolitismo. La ética en un mundo de extraños (traducción de Lilia Mosconi, $1^{a}$ edición-2 ${ }^{a}$ reimpresión). Katz Editores, Buenos Aires, 2012, pp. 78-79.
}

Facultad de Derecho y Ciencias Sociales - Universidad de Valparaíso - Chile 
Es oportuno precisar — siguiendo a Bhikhu Parekh—que para Oakeshott toda asociación humana se estructura en torno a prácticas, que éste clasifica en prudenciales y morales. Las prácticas prudenciales persiguen objetivos sustantivos comunes, mientras las prácticas morales son no instrumentales por definición. Esto significa que hay dos modos diferentes de asociación humana: (a) la asociación prudencial o "de empresa" - la universitas - , unida en función de un objetivo común, por alguna condición sustantiva de cosas que hayan de ser obtenidas conjuntamente, o por un interés común que haya que satisfacer de manera continua; (b) la asociación moral o "basada en la práctica" - la societas - , unida en función del reconocimiento de la autoridad de unas prácticas comunes. En este último tipo de asociación los miembros son libres de buscar objetivos sustantivos elegidos por ellos mismos (como los que participan en la práctica de la conversación de la humanidad $)^{108}$.

La idea del conocimiento como representación exacta tiende a concebirse como que ciertas clases de representaciones, expresiones o procesos son básicos, privilegiados y tienen carácter de fundamento. Una objeción fuerte a esta manera de entender la exactitud de la representación consiste en que sería imposible aislar elementos básicos sin que previamente exista un conocimiento de toda la estructura dentro de la que ocurren esos elementos. La noción de "representación exacta" (elemento por elemento) no podría sustituir, por ende, a la de realización con éxito de una práctica. "Nuestra elección de los elementos estará dictada por nuestra comprensión de la práctica, en vez de que la práctica esté 'legitimada' por una 'reconstrucción racional' a partir de elementos"109. Esta línea argumental — que Rorty llama "holística"sostiene que no seremos capaces de evitar el "círculo hermenéutico", esto es, el hecho de que no podemos entender las partes de una cultura, práctica, teoría, lenguaje o cualquier otra cosa desconocida, a menos

108. PAREKH, Bhikhu: Pensadores políticos contemporáneos (traducción de Vicente Bordoy, y revisión técnica de Fernando Vallespín). Alianza Editorial S.A., Madrid, 1986, pp. 129-130.

109. RORTY, Richard: La filosofía y el espejo..., cit., p. 290.

Revista de Ciencias Sociales - Número 65 (2014) - Universidad de Valparáíso - ISSN 0716-7725-Valparáiso, Chile 
que sepamos cómo funciona todo el conjunto, al tiempo que nos resulta imposible captar cómo funciona todo el conjunto, mientras no tengamos alguna comprensión de sus partes. "Esta idea de la interpretación indica que llegar a entender se parece más a tener conocimiento de una persona que a seguir una demostración. En ambos casos avanzamos y retrocedemos entre distintas opiniones sobre cómo caracterizar las afirmaciones particulares u otros hechos, y opiniones sobre el sentido de toda la situación, hasta que poco a poco nos vamos sintiendo a gusto con lo que hasta ahora nos era extraño" ${ }^{110}$. El planteamiento hermenéutico acerca del conocimiento se adecua bien a la idea de la cultura como una conversación más que como una estructura levantada sobre unos fundamentos ${ }^{111}$.

Según el filósofo argentino Daniel Kalpokas, la diferencia de dominios entre epistemología y hermenéutica sería sólo una diferencia de familiaridad: se es epistemólogo cuando se entiende perfectamente bien lo que sucede pero se necesita codificar el suceso para fundamentarlo; se es hermenéutico cuando no se entiende lo que sucede y se admite honestamente esta circunstancia. "Esto significa — dice el filósofo argentino- que podemos obtener conmensurabilidad epistemológica únicamente donde ya hemos acordado prácticas de investigación. Y podemos obtenerla, no porque hayamos descubierto la naturaleza del conocimiento humano, sino simplemente porque, cuando una práctica ha continuado lo suficiente, las convenciones que la hacen posible son relativamente fáciles de aislar" ${ }^{112}$. En circunstancias que la frontera entre ambos dominios no parece segura, hay autores - como Putnam, por ejemplo- que consideran que la esperanza de contar con un método formal de investigación, que pudiera ser aislado a partir de nuestros juicios sobre la naturaleza del mundo, parece haberse frustrado: "Y si ensanchamos la noción de un método de manera que una formalización de la psicología completa de un ser humano

\section{0. Íd., p. 291.}

111. Íd. ibíd.

112. KALPOKAS, Daniel: Richard Rorty y la superación pragmatista de la epistemología, cit., p. 38.

Facultad de Derecho y Ciencias Sociales - Universidad de Valparaíso - Chile 
idealmente racional cuente como un 'método', no hay razón para pensar que un 'método' en este sentido deba ser independiente de los juicios del ser humano sobre metafísica, estética o cualquier otra cosa” ${ }^{113}$.

El deseo de Rorty es desembarazarse de la noción de "correspondencia". Insistir en esta idea es regresar a la tesis de que el mundo o el yo tienen una naturaleza intrínseca. Pero en la perspectiva rortiana no se trata de desechar esta idea sin más: decir que cabe excluir el planteamiento de que la verdad está ahí fuera esperando a que la descubramos no significa sostener que ahí fuera no hay una verdad. Es apenas admitir que nuestros propósitos serían mejor satisfechos si dejáramos de considerar la verdad como una cuestión profunda, como un tema de interés filosófico, o como un término susceptible de análisis. Para Rorty la naturaleza de la verdad es un tema infructuoso, semejante en este respecto a la naturaleza del hombre o la naturaleza de Dios ${ }^{114}$.

Aun cuando Putnam opina que de la circunstancia de que construyamos hechos y valores no se deriva que éstos sean arbitrarios o que no puedan ser mejores o peores, comparte sin embargo con Rorty su rechazo al realismo metafísico. Así, arguye Putnam: “[...] la pregunta acerca de qué parte de nuestra telaraña de creencias refleja el mundo 'en sí mismo' y qué parte constituye nuestra 'contribución conceptual' no tiene más sentido que la pregunta: '¿Anda un hombre más esencialmente con su pierna izquierda o con su pierna derecha?'. El rastro de la serpiente humana está por todas partes" ${ }^{115}$.

113. PUTNAM, Hilary: Las mil caras del realismo (traducción de Margarita Vázquez Campos y Antonio Liz Gutiérrez, $1^{a}$ edición). PAIDÓS Ibérica S.A., Barcelona, 1994, p. 145.

114. RORTY, Richard: Contingencia, ironía y solidaridad (traducción de Alfredo Eduardo Sinnot, $1^{a}$ edición-5 ${ }^{a}$ impresión). ESPASA Libros S.L.U., Madrid, 2011, p. 28.

115. PUTNAM, Hilary: Las mil caras del realismo (traducción de Margarita Vázquez Campos y Antonio Liz Gutiérrez, $1^{a}$ edición). PAIDÓS Ibérica S.A., Barcelona, 1994, pp. 148-149; JAMES, William: Pragmatismo, cit., p. 67.

Revista de Ciencias Sociales - Número 65 (2014) - Universidad de Valparaíso - ISSN 0716-7725-Valparaíso, Chile 


\section{La filosofía como práctica social}

A la luz de las ideas de Davidson que entienden la distinción entre enunciabilidad y verdad sin referencia a reglas semánticas o sistemas conceptuales, sino como divisiones arbitrarias de un proceso inconsútil e interminable de tejer y retejer entramados de creencias y de criterios de enunciabilidad en transformación ${ }^{116}$, Richard Rorty defiende la estrategia antirrepresentacionalista consistente en abandonar la perspectiva divina y apelar a lo que nosotros hacemos como vía para resolver tradicionales problemas representacionalistas. Con ese "nosotros" el filósofo no se propone acudir a una expresión genérica vaga (equivalente, por ejemplo, a "humanidad"), sino que a una alusión concreta acerca de lo que los intervinientes hacen efectivamente. Así, aduce: "Éste me parece un paso trascendental, pues es el inicio del fin de [lo que Rosenberg ha denominado] el Mito de la Mente Separada. Abre el camino... a los boletos de inferencia y las pautas de razonamiento práctico — sus apelaciones a lo que nosotros hacemospara explicar el concepto de verdad, para afirmar la inducción, y para explicar el punto de vista moral. Pero semejantes apelaciones presuponen que una explicación filosófica de nuestra práctica no tiene que adoptar la forma de descripciones de nuestra relación con algo distinto a nosotros mismos, sino que meramente tiene que describir nuestra práctica" 117 . En tal sentido, siempre en sintonía con Davidson, admite que el concepto de verdad de las personas crea un lenguaje particular desde el momento en que un concepto de verdad así concebido es en parte autorreferencial: se explica lo verdadero en términos del lenguaje que cada persona conoce ${ }^{118}$.

El punto de partida no es el de un sujeto trascendental solitario, sino el particular de la historia en que nos encontramos. La discusión básica acerca de si es posible apelar a algo distinto, que está más allá de la manera en que nosotros vivimos ahora, o que nosotros hacemos ahora,

116. RORTY, Richard: Objetividad, relativismo y verdad, cit., p. 210.

117. Íd., pp. 213-214.

118. Íd., p. 215.

Facultad de Derecho y Ciencias Sociales - Universidad de Valparaíso - Chile 
o de nuestra forma de hablar ahora - de cualquier cosa que trascienda nuestro efímero momento de la historia (como dijera el poeta "somos efímeros, es cierto, pero por corto tiempo") — enfrenta a los filósofos del lenguaje representacionalistas con los de la práctica social. En opinión de Rorty, ésta es la cuestión decisiva entre un enfoque de la filosofía que da por supuesto el mito de la mente separada y otro que supone que se ha elaborado el propio conocimiento lingüístico o las propias pautas de razonamiento práctico y la manera en que se enfrenta al mundo la comunidad a la que pertenecemos ${ }^{119}$.

En el pensamiento rortiano no hay una negación total de la verdad, sólo un reconocimiento al carácter proposicional de la verdad, su adscripción a un lenguaje particular, con vistas a promover la idea de que es más factible que lo que llamamos "la verdad" se alcance en el encuentro libre de opiniones. Rorty manifiesta su extrañeza ante el enunciado "la verdad no existe", porque titubea en cuanto a qué pueda significar. A pesar del reproche que se le hace de ser un promotor de dicho enunciado, nuestro autor señala que sólo muy pocos filósofos lo defenderían. En su caso él recela de la distinción apariencia-realidad, si se atiende a la circunstancia de que existen muchas maneras de hablar de lo que sucede y que ninguna de ellas se acerca más que las otras al modo de ser de las cosas en sí mismas. La cuestión radica en que, como afirma Rorty, no tenemos idea qué significa el "en sí misma" de la expresión "la realidad tal como es en sí misma”. De allí que su propuesta sea abandonar la distinción apariencia-realidad en aras de una distinción entre maneras de hablar menos útiles y más útiles ${ }^{120}$.

Estando impedidos los pragmatistas de formular una teoría de la verdad se limitan a advertir que la verdad no es una meta de la investigación: si "verdad" es el nombre de esa meta, luego la verdad no existe porque el carácter absoluto de la verdad la torna inservible como meta. Los intentos por establecer la naturaleza, o la tarea o la misión de la filosofía usualmente buscan erigir una definición de "filosofía" a partir de las propias preferencias filosóficas ${ }^{121}$. "Una meta — precisa Rorty-

\footnotetext{
119. Íd., pp. 216-217.

120. RORTY, Richard: Verdad y progreso, cit., p. 11.

121. Íd., p. 21.

Revista de Ciencias Sociales - Número 65 (2014) - Universidad de Valparáíso - ISSN 0716-7725-Valparaíso, Chile
} 
es algo respecto de lo cual uno puede saber que se está acercando o que se está alejando. Pero no hay forma de saber a qué distancia estamos de la verdad, o siquiera si estamos más cerca que nuestros antepasados" ${ }^{122}$. El único criterio a nuestra disposición para aplicar verdadero a algo es la manera en que lo justificamos, y esta justificación es siempre relativa a un auditorio. La pregunta "¿conducen hacia la verdad nuestras prácticas de justificación?” a la par de ser apragmática, según Rorty es incontestable ${ }^{123}$.

La imagen kantiana de la unión de conceptos e intuiciones para generar el conocimiento se esgrime como necesaria para dar sentido a la idea de la "teoría del conocimiento" en cuanto disciplina específicamente filosófica, lo cual equivale a sostener que sin la distinción entre lo que es "dado" y lo que es "añadido por la mente", o entre lo "contingente" (influido por lo que es dado) y lo "necesario" (por estar totalmente "dentro de" la mente y bajo su control) no podría saberse que es lo que puede figurar como "reconstrucción racional" de nuestro conocimiento, ni cuál es el objetivo o el método de la epistemología ${ }^{124}$. Revitalizada por la diferencia positivista entre "verdadero en virtud del significado" y "verdadero en virtud de la experiencia”, dicha distinción, según Rorty, se mantuvo al margen de los debates y formó el común denominador del análisis del lenguaje ideal y del lenguaje ordinario. Con las dudas de Quine y Wittgenstein, agrega Rorty, acerca de cómo saber cuándo se responde a la compulsión del lenguaje y no a la de la experiencia, se tornó paulatinamente más difícil explicar en qué sentido la filosofía tenía un ámbito formal de investigación y "cómo era posible que sus resultados tuvieran el carácter apodíctico deseado" 125 . Alega Rorty que si se abandona la idea del conocimiento como representación precisa — como el Espejo de la Naturaleza — entonces puede suscribirse la tesis holista de que "la justificación no es cuestión de una relación

\footnotetext{
122. Íd., p. 14.

123. Íd. ibíd.

124. RORTY, Richard: La filosofía y el espejo..., cit., p. 160.

125. Íd., p. 161.
}

Facultad de Derecho y Ciencias Sociales - Universidad de Valparaíso - Chile 
especial entre ideas (o palabras) y objetos, sino de conversación, de práctica social... La premisa fundamental de este argumento es que entendemos el conocimiento cuando entendemos la justificación social de la creencia, y, por tanto, no tenemos ninguna necesidad de considerarlo como precisión en la representación” ${ }^{126}$.

Se cuestiona Rorty si es posible tratar el estudio de la naturaleza del conocimiento humano sólo como el estudio de ciertas formas en que interactúan los seres humanos, o si también requiere un fundamento ontológico ${ }^{127}$. La primera alternativa, comenta nuestro autor, conduce a una concepción pragmática de la verdad y a un enfoque terapéutico de la ontología (para disolver disputas entre sentido común y ciencia); la segunda, lleva a explicaciones ontológicas de las relaciones entre mentes y significados, mentes y datos inmediatos de conciencia, universales y particulares, conciencia y cerebros, y así (algunos filósofos estiman que deben intentarse tales explicaciones para mantener el realismo del sentido común). Elegir entre estos enfoques es elegir entre la verdad como lo que es bueno que creamos y la verdad como contacto con la realidad ${ }^{128}$. Lo que no puede hacerse, sostiene Rorty, es considerar el conocimiento de entidades internas o abstractas, como "conceptos a priori" o "ideas innatas", como premisas de las que se infiere normalmente nuestro conocimiento de otras realidades, y sin las cuales este último conocimiento "carecería de base" 129.

La diferencia entre las alternativas antes descritas es similar, en opinión de Rorty, a la que hay entre los filósofos morales que piensan que los derechos y responsabilidades dependen de lo que decida la sociedad y los que piensan que hay algo dentro del hombre que la sociedad reconoce al tomar sus decisiones. Ambas escuelas defienden los derechos humanos, pero se distancian cuando una vez que se comprende cuándo y por qué se concedieron o negaron estos derechos

\footnotetext{
126. Íd., pp. 161-162.

127. Íd., p. 166.

128. Íd. ibíd.

129. Íd., p. 167.
}

Revista de Ciencias Sociales - Número 65 (2014) - Universidad de Valparáíso - ISSN 0716-7725-Valparaíso, Chile 
con arreglo a circunstancias históricas y sociales concretas, se piensa que "queda algo más por entender" ${ }^{130}$. La cuestión radica en establecer si es coherente que la autoridad epistémica o moral tenga una "base" en la naturaleza. Para los pragmáticos en el campo de la moral la afirmación de que las costumbres de una determinada sociedad están "basadas en la naturaleza humana" no es algo de lo que quepa argumentar, porque no ven qué es eso "de que una costumbre esté basada”. Nada figura como justificación a no ser por referencia a lo que aceptamos ya: no es posible escapar de nuestras creencias ni de nuestro lenguaje para hallar una prueba que esté más allá. El conocimiento de los conceptos no es previo al conocimiento de las proposiciones, sino una abstracción de éstas: no existe ninguna creencia justificada que sea no-proposicional, y ninguna justificación que no sea una relación entre proposiciones $^{131}$.

En idéntico sentido Habermas, en su interpretación del pensamiento rortiano, reconoce que incluso en la comprensión de enunciados elementales relativos a estados o sucesos en el mundo el lenguaje y la realidad se interpenetran indisolublemente, por lo que no podemos escapar del círculo de nuestro lenguaje ${ }^{132}$. De allí que se abra paso un concepto antifundamentalista del conocimiento y uno holista de justificación: “[...] no pueden distinguirse enunciados básicos que tuvieran el privilegio de legitimarse por sí mismos y pudieran servir como base de una cadena lineal de fundamentación” ${ }^{133}$.

\section{A modo de conclusión}

Dicho sintéticamente, en el pensamiento pragmatista de Richard Rorty destaca su rechazo a la idea de que los seres humanos tengamos

\footnotetext{
130. Íd., p. 168.

131. Íd., pp. 168 y 172.

132. HABERMAS, Jürgen: El giro pragmático de Rorty (traducción de Pere Fabra). En: Revista ISEGORÍA N 17,1997 , p. 17.

133. Íd. ibíd.
}

Facultad de Derecho y Ciencias Sociales - Universidad de Valparaíso - Chile 
un acceso privilegiado a la "verdad". Vincula esta imposibilidad con cierto fracaso de la filosofía desde el momento en que ésta ha planteado tradicionalmente dicho acceso como su objetivo último. A partir de este diagnóstico Rorty propone dos cosas principales: por una parte, la autodisolución de la filosofía en una más saludable y liberal cultura postfilosófica articulada en torno a las ciencias, las humanidades y las artes; por otra, que la certeza de nuestros conocimientos no depende de la mayor o menor exactitud con la que nos representemos las cosas que afirmamos conocer, sino de la justificación social de nuestras creencias al respecto, esto es, "[que] la corrección de nuestro conocimiento putativo se resuelve conversacionalmente" 134 .

En ese orden podría sintetizarse la crítica rortiana a la epistemología, como sigue ${ }^{135}$ :

1. El término "conocimiento" no esconde ninguna esencia a desentrañar. Abandonadas las nociones de representación privilegiada, de condiciones de posibilidad del conocimiento y de fundamentación, el conocimiento humano deja de ser un objeto de estudio para la filosofía.

2. La comunidad es la fuente de toda autoridad epistémica. Y como es implausible una aprehensión de objetos (mentales o no) independiente del lenguaje, todo conocimiento lo es por descripción. La idea de una aprehensión inmediata de las cosas cede a favor de una concepción conversacional del conocimiento: el conocimiento del mundo es conocimiento de proposiciones consensuadas.

3. Para el conversacionalismo rortiano el conocimiento es aquello que estamos justificados en creer, y la justificación es un fenómeno social y no una transacción entre el sujeto cognoscente y la realidad. La objetividad se disuelve en la solidaridad (o intersubjetividad) y el significado de las palabras depende del significado de otras

134. PÉREZ CHICO, David: Visiones de la contingencia. Escepticismo, ironía liberal y perfeccionismo moral. En: La filosofía de Richard Rorty. Entre pragmatismo y relativismo (Juan José Colomina y Vicente Raga, editores). Editorial Biblioteca Nueva S.L., Madrid, 2010, pp. 228-229.

135. KALPOKAS, Daniel: Richard Rorty y la superación..., cit., pp. 42 y ss.

Revista de Ciencias Sociales - Número 65 (2014) - Universidad de Valparáíso - ISSN 0716-7725-Valparáiso, Chile 
palabras, no de su carácter representativo. Las únicas coacciones que posee la conversación son las que provienen de nuestros pares.

4. Las creencias no son copias o imágenes de la realidad, sino hábitos de acción. Las descripciones de la realidad pueden ser mejores o peores, pero esta evaluación sólo puede efectuarse en función de propósitos e intereses.

5. El etnocentrismo (o contextualismo) rortiano supone que los patrones de justificación y los estándares de racionalidad son siempre relativos a comunidades histórica y geográficamente situadas. En cada caso son nuestros criterios. No es posible saltar fuera de nuestra comunidad para confrontar nuestras creencias con una verdad desnuda.

\section{BIBLIOGRAFÍA CITADA}

APPIAH, Kwame Anthony: Cosmopolitismo. La ética en un mundo de extraños (traducción de Lilia Mosconi, $1^{a}$ edición-2 ${ }^{a}$ reimpresión).

Katz Editores, Buenos Aires, 2012.

BADIOLA, Susana: Introducción. El naturalismo filosófico de P.F. Strawson: inevitabilidad natural y aceptabilidad metafísica. En:

Escepticismo y naturalismo: algunas variedades (traducción de Susana

Badiola). A. Machado Libros S.A., Madrid, pp. 9-36, 2003.

BELLO REGUERA, Gabriel: Introducción. Richard Rorty en la encrucijada de la filosofía postanalítica: entre pragmatismo y hermenéutica. En: El giro lingüistico, Richard Rorty (traducción de Gabriel Bello, $1^{a}$ reimpresión). PAIDÓS Ibérica S.A., Barcelona, 1998.

DAVIDSON, Donald: De la verdady de la interpretación. Fundamentales contribuciones a la filosofía del lenguaje (traducción de Guido

Filippi, $2^{a}$ reimpresión). Editorial GEDISA S.A., Barcelona, 2001.

— Subjetivo, intersubjetivo, objetivo (traducción de Olga Fernández Prat, $1^{a}$ edición). Ediciones Cátedra (Grupo Anaya S.A.), Madrid, 2003.

DEWEY, John: La miseria de la epistemología. Ensayos de pragmatismo (traducción de Ángel M. Faerna). Editorial Biblioteca Nueva S.L., Madrid, 2010.

Facultad de Derecho y Ciencias Sociales - Universidad de Valparaíso - Chile 
DUICA, William: Acerca del debate realismo-antirrealismo. En: Revista Ideas y Valores $\mathrm{N}^{\circ} 120$, Universidad Nacional de Colombia, diciembre de 2002, Bogotá, pp. 106-114, 2002.

DUMMETT, Michael: La verdad y otros enigmas (traducción de Alfredo Herrera Patiño). Fondo de Cultura Económica S.A de C.V., México D.F., 1990.

FAERNA, Ángel Manuel: Introducción. En: La miseria de la epistemología. Ensayos de pragmatismo, John Dewey (traducción de Ángel M. Faerna). Editorial Biblioteca Nueva S.L., Madrid, pp. 9-24, 2010.

GOETHE, Norma B.: Introducción: Putnam y la lectura de los modernos.

En: Sentido, sinsentido y los sentidos (traducción de Norma B. Goethe). PAIDÓS Ibérica S.A., Barcelona, pp. 17-44, 2000.

HABERMAS, Jürgen: El giro pragmático de Rorty (traducción de Pere

Fabra). En: Revista ISEGORÍA N 17-1997, pp. 5-36. Recuperado de http://isegoria.revistas.csic.es, 1997.

JAMES, William: Pragmatismo (traducción de Luis Rodríguez Aranda, $3^{a}$ edición). Editorial AGUILAR-Biblioteca de Iniciación Filosófica, Buenos Aires, 1961.

KALPOKAS, Daniel: Richard Rorty y la superación pragmatista de la epistemología (1 $1^{a}$ edición). Ediciones del Signo, Buenos Aires, 2005.

LIZ, Manuel: Introducción. En: La herencia del pragmatismo, Hilary Putnam (traducción de Manuel Liz y Margarita Vázquez, $1^{a}$ edición). PAIDÓS Ibérica S.A., Barcelona, pp. 9-15, 1997.

PAREKH, Bhikhu: Pensadores políticos contemporáneos (traducción de Vicente Bordoy, y revisión técnica de Fernando Vallespín). Alianza Editorial S.A., Madrid, 1986.

PÉREZ CHICO, David: Visiones de la contingencia. Escepticismo, ironía liberal y perfeccionismo moral. En: La filosofía de Richard Rorty. Entre pragmatismo y relativismo (Juan José Colomina y Vicente Raga, editores). Editorial Biblioteca Nueva S.L., Madrid, pp. 225-244, 2010. PUTNAM, Hilary: El significado y las ciencias morales (traducción de

Ana Isabel Stellino). Universidad Nacional Autónoma de México, Instituto de Investigaciones Filosóficas, Colección Cuadernos $\mathrm{N}^{\circ} 55$, México D.F., 1991. 
_ Las mil caras del realismo (traducción de Margarita Vázquez Campos y Antonio Liz Gutiérrez, $1^{a}$ edición). PAIDÓS Ibérica S.A., Barcelona, 1994.

_- La herencia del pragmatismo (traducción de Manuel Liz y Margarita Vázquez, $1^{a}$ edición). PAIDÓS Ibérica S.A., Barcelona, 1997.

—_ Sentido, sinsentido y los sentidos (traducción de Norma B. Goethe). PAIDÓS Ibérica S.A., Barcelona, 2000.

_- El pragmatismo. Un debate abierto (traducción de Roberto Rosaspini Reynolds, $1^{a}$ edición-1 $1^{a}$ reimpresión). Editorial GEDISA S.A., Barcelona, 2006.

PUTNAM, Ruth Anna: La lógica de Dewey: Epistemología como hipótesis. En: La herencia del pragmatismo, Hilary Putnam (traducción de Manuel Liz y Margarita Vázquez, $1^{a}$ edición). PAIDÓS Ibérica S.A., Barcelona, pp. 215-249, 1997.

QUINE, Willard Van Orman: La relatividad ontológica y otros ensayos (traducción de Manuel Garrido y Josep Ll. Blasco, $1^{a}$ edición-2 ${ }^{a}$ reimpresión). Editorial TECNOS (Grupo Anaya S.A.), Madrid, 2002. QUINTANILLA, Miguel Ángel: Introducción: El realismo necesario. En: Las mil caras del realismo, Hilary Putnam (traducción de Margarita Vázquez Campos y Antonio Liz Gutiérrez, $1^{a}$ edición). PAIDÓS Ibérica S.A., Barcelona, pp. 17-35, 1994.

RORTY, Richard: Objetividad, relativismo y verdad (traducción de Jorge Vigil, $1^{a}$ edición). PAIDÓS Ibérica S.A., Barcelona, 1996.

RORTY, Richard: Consecuencias del pragmatismo (traducción de José Miguel Esteban Cloquell). Editorial TECNOS S.A., Madrid, 1996.

RORTY, Richard: Pragmatismo y política (traducción de Rafael del Águila, $1^{a}$ edición). PAIDÓS Ibérica S.A., Barcelona, 1998.

RORTY, Richard: Notas sobre desconstrucción y pragmatismo. En: Desconstrucción y pragmatismo. Compilación de Chantal Mouffe (traducción de Carlos Mayer, $1^{a}$ edición). PAIDÓS SAICF, Buenos Aires, 1998.

RORTY, Richard: Verdad y progreso (traducción de Ángel Manuel Faerna García-Bermejo). PAIDÓS Ibérica S.A., Barcelona, 2000.

RORTY, Richard: La filosofía y el espejo de la naturaleza (traducción de Jesús Fernández Zulaica, $6^{a}$ edición). Ediciones Cátedra (Grupo Anaya S.A.), Madrid, 2010.

Facultad de Derecho y Ciencias Sociales - Universidad de Valparaíso - Chile 
RORTY, Richard: Contingencia, ironía y solidaridad (traducción de Alfredo Eduardo Sinnot, $1^{a}$ edición-5a impresión). ESPASA Libros S.L.U., Madrid, 2011.

STRAWSON, Peter F.: Escepticismo y naturalismo: algunas variedades (traducción de Susana Badiola). A. Machado Libros S.A., Madrid, 2003.

Revista de Ciencias Sociales - Número 65 (2014) - Universidad de Valparáíso - ISSN 0716-7725-Valparaíso, Chile 